\title{
Dejavniki tveganja in psihološka obravnava kronične bolečine pri otrocih in mladostnikih
}

\author{
Barbara Horvat Rauter* \\ Univerzitetni rehabilitacijski inštitut RS - Soča
}

\begin{abstract}
Povzetek: V prispevku smo predstavili sistematični pregled dejavnikov tveganja za razvoj kronične bolečine pri otrocih in mladostnikih ter njihovo psihološko obravnavo. Opisali smo individualne in medosebne dejavnike tveganja za razvoj kronične bolečine pri otrocih in mladostnikih. Kronično spoprijemanje z bolečino lahko pušča pri otrocih in mladostnikih tudi pomembne posledice, ki se kažejo v posameznikovi kakovosti življenja, njegovem miselnem delovanju, doživljanju sebe in telesa, vključevanju v vrstniške skupine ter športne aktivnosti in vključevanju v šolo. Učinkovita obravnava kronične bolečine je interdisciplinarna, kjer je pomemben tudi psihološki del. V prispevku smo opisali značilnosti kliničnopsihološke ocene in ocene bolečine ter kliničnopsihološke terapevtske pristope in tehnike, $v$ katere vključimo značilnosti, ki smo jih prepoznali skozi oceno in lahko vplivajo na krepitev in/ali vzdrževanje kronične bolečine.
\end{abstract}

Ključne besede: kronična bolečina, otroci, mladostniki, dejavniki tveganja, psihološki pristop

\section{Risk factors and psychological treatment of chronic pain in children and adolescents}

\author{
Barbara Horvat Rauter* \\ University Rehabilitation Institute - Soča, Ljubljana, Slovenia
}

\begin{abstract}
This contribution is a systematical overview of risk factors and psychological treatment of children and adolescents with chronic pain syndrome. The paper describes a wide range of individual and interpersonal risk factors for development of chronic pain in children and adolescents. Dealing with chronic pain leaves in children and adolescents important consequences, which are reflected in the individual's quality of life, cognitive functioning, experience of self and body, integration in the peer group and sports activities, and the inclusion in the school. Effective treatment of chronic pain is interdisciplinary and the psychological approach represents an important part of it. In this contribution, we described the psychological assessment of the individual and it's pain. We also addressed psychotherapeutic interventions, which are tied to the individual and his family.
\end{abstract}

Keywords: chronic pain, children, adolescents, risk factors, psychological approach

\footnotetext{
*Naslov/Address: dr. Barbara Horvat Rauter, Oddelek za (re)habiitacijo otrok, Univerzitetni rehabilitacijski inštitut RS - Soča, Linhartova 51, 1000 Ljubljana, e-mail: barbara.rauter@ir-rs.si
}

Članek je licenciran pod pogoji Creative Commons Attribution 4.0 International licence. (CC-BY licenca). The article is licensed under a Creative Commons Attribution 4.0 International License (CC-BY license). 
Bolečina je večrazsežnostna izkušnja, saj vključuje tako neprijetno telesno kot tudi čustveno izkušnjo, ki je povezana $\mathrm{z}$ dejansko ali možno poškodbo oziroma okvaro tkiva. $\mathrm{Z}$ izkušnjo bolečine se srečujemo že od majhnega. Večinoma s prehodno, akutno bolečino, ki ima jasen telesni izvor in ob vplivanju nanj izzveni. Nekateri pa se spoprijemajo tudi s trajajočo kronično bolečino. Oblika bolečine, ki jo obravnavamo $\mathrm{v}$ prispevku, je sindrom kronične razširjene bolečine, ki ni rakavega izvora in je po kriterijih American College of Rheumatology (ACR) opredeljena kot vsaj tri mesece trajajoča bolečina. $\mathrm{V}$ prispevku smo se osredotočili na populacijo otrok in mladostnikov. Aktualne ocene kažejo, da naj bi se en od štirih otrok v času svojega otroštva spoprijemal z vsaj eno epizodo kronične bolečine, ki traja tri mesece ali dlje (Coakley in Wihak, 2017; King idr., 2011); 3-5 \% otrok in najstnikov pa trpi zaradi kronične bolečine (Stahlschmidt, Zernikow in Wager, 2016). Tovrstna trajajoča bolečina je namreč povezana $\mathrm{z}$ značilnimi telesnimi, psihološkimi in psihosocialnimi ovirami tako za otroka kot tudi za družino in ostale sisteme, v katere je otrok vključen (Palermo, 2000; Eccleston in Crombez, 2017). Zaradi tega je prepoznavanje in obravnava bolečine pri otrocih ključnega pomena. Nemalokrat se namreč zgodi, da se kronična bolečina iz otroštva preko najstniškega obdobja prenese v odraslost (Walker, Dengler-Crish, Rippel in Bruehl, 2010). Raziskave kažejo, da naj bi $80 \%$ odraslih oseb s kronično bolečino poročalo o pojavnosti bolečine $\mathrm{v}$ otroštvu ali mladostništvu in njenem nadaljevanju v odraslo dobo. Lahko pa je tudi izzvenela in se ponovno pojavila v odraslosti (Hassett idr., 2013).

Kronična bolečina je bila najprej obravnavana po biomedicinskem modelu, ki je usmerjen na bolezen, okvaro, patologijo, zato je zdravje opredeljeno kot odsotnost bolezni. Glavni predmet obravnave je telo, organ, tkivo, celica. Vsi diagnostični in terapevtski postopki (npr. fizikalni, kirurški, farmakološki) so usmerjeni na ta model. Model je objektiven, psihosocialni dejavniki so zanj sekundarnega pomena. Ker pa je skozi čas v obravnavi bolečine postajalo posameznikovo doživljanje bolečine vse pomembnejše, se je uveljavil biopsihosocialni model. Poleg bioloških vključuje še psihološke, socialne in kulturne dejavnike. Enota obravnave tako ni bolezen, ampak posameznik.

Tabela 1. Prikaz biopsihosocialnih teorij razvoja kronične bolečine in terapevtska izhodišča (povzeto po Carr, 2016)

\begin{tabular}{|c|c|c|c|}
\hline Teorija & & Teoretična izhodišča & Terapevtska izhodišča \\
\hline \multirow[t]{2}{*}{$\begin{array}{l}\text { Znotrajpsihične } \\
\text { teorije }\end{array}$} & Psihoanalitična teorija & $\begin{array}{l}\text { Anksioznost, ki jo povzročajo nezavedni } \\
\text { konflikti, se pretvori v fizične simptome } \\
\text { bolečine, ki so znosnejši od doživljanja } \\
\text { anksioznosti. } \\
\text { Otroci posledično doživljajo manj } \\
\text { anksioznosti (primarna pridobitev), } \\
\text { bolečina pa jim omogoča, da se v večji } \\
\text { meri izognejo neprijetnim aktivnostim } \\
\text { ter s strani drugih dobijo več pozornosti } \\
\text { (sekundarna pridobitev). }\end{array}$ & $\begin{array}{l}\text { Individualna terapevtska obravnava, } \\
\text { kjer se skozi terapevtski odnos čustva, } \\
\text { ki so vezana na nerazrešen konflikt, } \\
\text { projicirajo na terapevta. } \\
\text { Predelujejo se konfliktna čustva ter } \\
\text { pomen primarnih in sekundarnih } \\
\text { pridobitev. }\end{array}$ \\
\hline & Psihosomatska teorija & $\begin{array}{l}\text { Kronična bolečina otrokom omogoča, da o } \\
\text { svojih težkih občutkih poročajo drugim. } \\
\text { Otroci, ki imajo težave z zavedanjem in } \\
\text { izražanjem lastnih čustev, ali pa imajo za } \\
\text { sabo izkušnjo lastne bolezni ali bolezni } \\
\text { bližnjih, poročajo o stresu preko soma- } \\
\text { tizacije. }\end{array}$ & $\begin{array}{l}\text { Psihoterapevtska obravnava, v kateri } \\
\text { se raziskuje in interpretira funkcija } \\
\text { simptoma (bolečine). } \\
\text { Hipnoterapija, v kateri skuša terapevt } \\
\text { skozi sugestije zmanjšati simptom. }\end{array}$ \\
\hline \multirow{3}{*}{ Medosebne teorije } & Vedenjska teorija & $\begin{array}{l}\text { Vzorci vedenja so ob akutni bolečini z } \\
\text { mehanizmom ojačanja (model instrumen- } \\
\text { talnega in klasičnega pogojevanja) ohran- } \\
\text { jeni dalj časa in lahko postanejo kronični. }\end{array}$ & $\begin{array}{l}\text { Delo na vedenjskih spremem- } \\
\text { bah - ojačevanje, nagrajevanje } \\
\text { primernega vedenja ter zmanjševanje } \\
\text { bolezenskega. }\end{array}$ \\
\hline & $\begin{array}{l}\text { Kognitivno-vedenjske } \\
\text { teorije }\end{array}$ & $\begin{array}{l}\text { Bolečina ima biološke, zaznavne, kog- } \\
\text { nitivne, čustvene in vedenjske dimenzije } \\
\text { v medosebnih odnosih, ki so med seboj } \\
\text { kompleksno prepletene. }\end{array}$ & $\begin{array}{l}\text { Trening sproščanja za zmanjševanje } \\
\text { vzburjenja. } \\
\text { Kognitivni trening, kognitivna re- } \\
\text { strukturacija, učenje spoprijemanja s } \\
\text { stresom. }\end{array}$ \\
\hline & $\begin{array}{l}\text { Družinska, sistemska } \\
\text { teorija }\end{array}$ & $\begin{array}{l}\text { Specifični neprilagojeni procesi in } \\
\text { družinski vzorci (npr. ločitev staršev, } \\
\text { slabi odnosi, nasilje ...) krepijo dejavnike } \\
\text { tveganja za razvoj kronične bolečine pri } \\
\text { otrocih. } \\
\text { Intenzivnost simptomov, ki jih otrok } \\
\text { razvije, je odvisna od otrokove lastne } \\
\text { psihofiziološke dovzetnosti. }\end{array}$ & $\begin{array}{l}\text { Družinska terapija s poudarkom na } \\
\text { neprilagojenih družinskih vzorcih. }\end{array}$ \\
\hline
\end{tabular}


Vrstniški, socialni dejavniki Npr. podpora vrstnikov, vrstniško nasilje, izguba ali pomanjkanje kvalitetnih odnosov z vrstniki

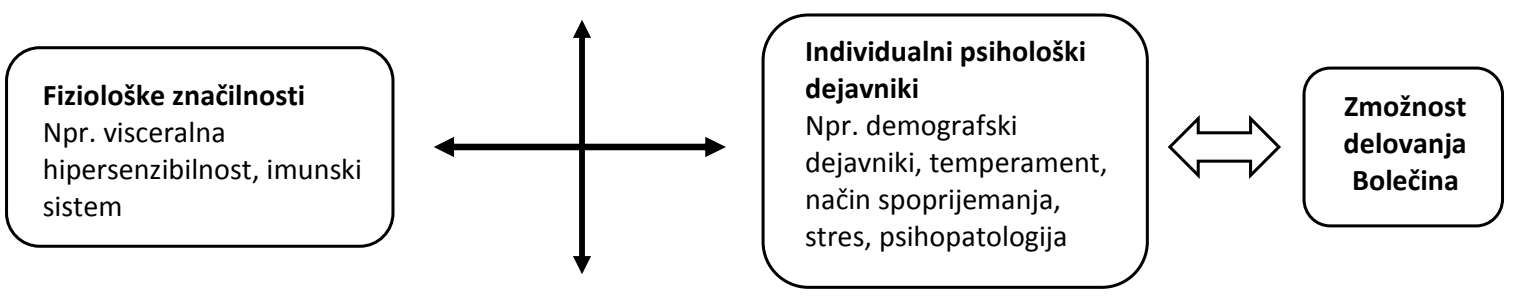

Družinski dejavniki

Npr. družinsko okolje, vzgojni stil, psihopatologija staršev, oblika navezanosti

čas

razvojna stopnja

Slika 1. Umestitev biopsihosocialnih dejavnikov v razvojno perspektivo (povzeto po McKillop in Benez, 2016).

Obravnava bolečine je preko biopsihosocialnega modela postala vse pomembnejša tudi za psihologe, ki so zavzeli pomembno mesto $\mathrm{v}$ procesu obravnave bolečine (Carr, 2016; Scottish Government, 2018). Pojavili so se različni psihološki modeli in teorije, ki poskušajo pojasniti prehod akutne bolečine $\mathrm{v}$ kronično, ter pojav bolečine, ki nastane brez očitnega, znanega ali vsaj utemeljeno predpostavljenega fizičnega ali organskega vzroka.

Najpomembnejše teorije, ki razlagajo kronično bolečino in predstavljajo izhodišča za različne vrste psiholoških pristopov in terapij, deli Carr (2016) na i) biološke, (ii) znotrajpsihične in (iii) medosebne teorije. Biološke teorije razlagajo razvoj bolečine po biomedicinskem modelu in predpostavljajo otrokove biološke značilnosti kot osnovne za razvoj kronične bolečine. Znotrajpsihične in medosebne pa ustrezajo biopsihosocialnemu modelu. Te teorije smo natančneje opisali v tabeli 1.

\section{Dejavniki tveganja za razvoj kronične bolečine}

Poznavanje dejavnikov, ki vplivajo na to, da akutna bolečina preraste $\mathrm{v}$ kronično, lahko pomembno doprinese $\mathrm{k}$ razvoju učinkovitih pristopov pri obravnavi bolečine. Čeprav je bilo opravljenih že precej raziskav o dejavnikih tveganja za razvoj kronične bolečine, so mehanizmi nastanka bolečine še slabo poznani. Za poznavanje vzdrževanja bolečinskega stanja je dragoceno razumevanje interakcij med temi dejavniki.
Kot smo že pisali, je kronična bolečina biopsihosocialna izkušnja in tudi dejavniki tveganja za razvoj bolečine predstavljajo kombinacijo individualnih (znotrajpsihičnih) in medosebnih dejavnikov. Na podlagi pregleda različnih študij smo dejavnike tveganja za razvoj kronične bolečine prikazali v štirih skupinah: posameznikove fiziološke in psihološke značilnosti kot individualne dejavnike; vrstniške dejavnike (in druge pomembne socialne odnose) ter družinske odnose kot medosebne dejavnike (McKillop in Banez, 2016). Prikazali smo jih na sliki 1 . Ti dejavniki se različno povezujejo skozi čas in glede na posameznikovo razvojno stopnjo.

\section{Individualni dejavniki}

\section{Demografski dejavniki}

Demografski dejavniki zajemajo starost, spol in raso. Kronična razširjena bolečina in bolečina v križu se pogosteje pojavljata $\mathrm{v}$ mladostništvu kot $\mathrm{v}$ otroštvu, kar avtorji pojasnjujejo kot posledico hormonskih sprememb, ki jih prinaša puberteta (Balague, Troussier in Salminen, 1999; Speretto, Brachi, Vittadello in Zulian, 2015). Pogosteje se s tovrstno bolečino srečujejo dekleta kot fantje (Speretto idr., 2015; Huguet idr., 2016; Wang, Fuh, Lu in Juang, 2006). Rasa kot dejavnik tveganja je bila pri populaciji odraslih obolelih predmet številnih raziskav, pri populaciji otrok in mladostnikov pa jo redkeje vključujejo. Izsledki kažejo, da rasa ni dejavnik tveganja za razvoj kronične bolečine (Gold, Mahrer, Yee in Palermo, 2009). 


\section{Temperament}

Temperament predstavlja kombinacijo razpoloženja, dnevnih navad in pozornostnih kapacitet (Conte, Walco in Kimura, 2003). Otroci s kronično bolečino za razliko od populacije otrok brez bolečine izkazujejo znižano razpoloženje, nerednost $\mathrm{v}$ dnevnih navadah, nižje kapacitete usmerjenosti na naloge in pomembno višjo odkrenljivost. Temperament pomembno sooblikuje otrokov način spoprijemanja in s tem otrokov odgovor na bolečino (Compas, 1987).

\section{Psihične težave in duševne motnje}

Pojavnost kronične razširjene bolečine je povezana s številnimi psihološkimi dejavniki, kot so anksioznost, depresija in vedenjske motnje. Rezultati študij kažejo, da pri otrocih in mladostnikih $\mathrm{z}$ anksiozno simptomatiko obstaja večje tveganje za razvoj kronične bolečine (Di Lorenzo idr., 2005; Egger, Costello, Erkanli in Angold, 1999; Tegethoff, Belardi, Stalujanis in Meinlschmidt, 2015). Nagnjenost k anksioznosti je opredeljena kot stopnja doživljanja telesnih, psiholoških in socialnih posledic. Ljudje z visoko dovzetnostjo za anksioznost doživljajo pomembno več negativnih posledic na omenjenih področjih (Page, Stinson, Campbell, Isaac in Katz, 2013). Izsledki longitudinalne študije kažejo, da je visoka dovzetnost za anksioznost ključen dejavnik pri razvoju akutne pooperativne bolečine v kronično. Pogosto se sočasno z anksiozno simptomatiko pojavlja tudi depresivna simptomatika; $16 \%$ mladostnikov izkazuje tveganje za razvoj depresije, pri tistih s kronično bolečino pa ta delež znaša $45 \%$. Manjše število raziskav opisuje povezavo med travmo in kronično bolečino. Primarno se osredotočajo na zlorabe (spolne, fizične in psihične) ali poškodbe (npr. nesreče, športne poškodbe) (Holley, Wilson, Noel, Palermo, 2016). Posttravmatska simptomatika v zgodnjem življenjskem obdobju napoveduje razvoj funkcionalnih motenj in kronične bolečine v kasnejši odrasli dobi (Holley idr., 2016). Kot dejavnike, ki doprinašajo k razvoju kronične bolečine, različni avtorji navajajo tudi nadpovprečno doživljanje jeze (Nicholson, Houle, Rhudy in Norton, 2007), motnje pozornosti s hiperaktivnostjo (Egger idr., 1999) in vedenjske motnje (Jones, Watson, Silman, Symmons in Macfarlane, 2003).

\section{Način spoprijemanja}

Način spoprijemanja s stresom pomeni zmožnost uravnavanja čustvovanja, mišljenja, vedenja, fizioloških odzivov ter okoljskih dejavnikov pri odgovoru na stresno situacijo ali dogodek. Pri otrocih in mladostnikih je način spoprijemanja vezan na njihovo razvojno stopnjo, saj $\mathrm{v}$ določenih razvojnih obdobjih še nimajo sposobnosti za učinkovite načine spoprijemanja (Compas, Connor-Smith, Saltzman, Thomsen in Wadsworth, 2001). Za otroke in mladostnike s kronično bolečino velja podobno kot za odrasle, in sicer, da prevladuje manj učinkovit način spoprijemanja, za katerega je značilno zanikanje, odvisnost od drugih, katastrofično doživljanje bolečine in življenjskih situacij (Litt, Shafer, Ibanez, Kreutzer in Tawfik-Yonkers, 2009).

\section{Fiziološke značilnosti}

Na sliki 1 smo prikazali tudi fiziološke značilnosti, ki so prepletene s posameznikovimi psihičnimi lastnostmi ter povečujejo tveganje za razvoj kronične bolečine. Otroci, ki razvijejo kronično bolečino, so bolj dovzetni za dražljaje iz okolja. Hitreje se vzburijo in težje umirijo. Njihov imunski sistem je slabši (McKillop in Banez, 2016).

\section{Medosebni dejavniki}

Kot je prikazano na sliki 1, umeščamo v skupino medosebnih dejavnikov odnose v primarnem okolju (družina), v sekundarnih okoljih, v katere otroci in mladostniki vstopajo (npr. vrtec, šola, prijatelji, interesne združbe), vplive okolja in kulture. Medosebni dejavniki predstavljajo zelo široko področje, zato smo posebej opisali vplive primarnega družinskega okolja in posebej vplive sekundarnega, vrstniškega okolja.

Palermo, Valrie in Karlson (2014) navajajo, da deluje družina na otroka preko dveh ravni, in sicer preko dejavnikov na ravni družine in preko dejavnikov na ravni staršev. Grafični prikaz smo podali na sliki 2. Družina je opredeljena kot kompleksen, medsebojno povezan sistem, ki deluje kot enota, $\mathrm{z}$ namenom vzdrževanja notranjega ravnovesja in reda (Goldenberg in Goldenberg, 2008). Ko se otrok spoprijema $\mathrm{Z}$ bolečino, posledice občuti cela družina (Palermo idr., 2014). Avtorji (Lewandowski, Palermo, Stinson, Handley in Chambers, 2010) so ugotovilu, da je v družinah otrok in mladostnikov, ki se spoprijemajo s kronično bolečino, prisotno na splošno manj funkcionalno družinsko delovanje. Kaže se v manj učinkoviti organizaciji, nižji koheziji in pogostejših konfliktih v primerjavi z družinami z otroki in mladostniki brez kroničnih bolečin. Posamezniki, pri katerih se razvije kronična bolečina, poročajo o pogostih konfliktih in nasilju v primarni družini v času njihovega otroštva (Voerman idr., 2015).

Poglejmo še dejavnike na ravni staršev, ki doprinašajo $\mathrm{k}$ razvoju kronične bolečine pri otrocih in mladostnikih. Otroci, pri katerih se razvije kronična bolečina, imajo pogosto pomanjkljivo odzivne starše in so na nek način spregledani (Brattberg, 1994), ali pa živijo v enostarševskih družinah (Chitkara, Rawat in Talley, 2005). Prevalenca duševnih bolezni pri starših otrok in mladostnikov s kronično bolečino je višja. Pogosta je anksiozno-depresivna simptomatika in težje duševne motnje. Vedenjske teorije nastanka kronične bolečine zagovarjajo pomen učenja bolečinskega vzorca vedenja od staršev (Palermo idr., 2014) in raziskave potrjujejo, da imajo otroci staršev z različnimi oblikami kronične bolečine višjo stopnjo tveganja za razvoj kronične bolečine (Balague idr., 1995; Balague idr., 1999; Chitkara idr., 2005). Na ravni odnosa s starši se oblikuje tudi otrokova navezanost, ki vsebuje tri pomembne dejavnike, ki lahko doprinašajo k razvoju kronične bolečine: (a) vzorec izražanja čustev (ponotranjanje, pozunanjenje); (b) vzorec vedenjskega odziva na zaznano grožnjo in (c) kognitivna ocena ogrožajoče situacije. Otroci, ki razvijejo kronično bolečino, so na vseh treh omenjenih področjih manj učinkoviti, saj pri njih prevladuje nevaren stil navezanosti (Donnelly in Jaaniste, 2016). Za razvoj bolečinske simptomatike pa niso zadostni 


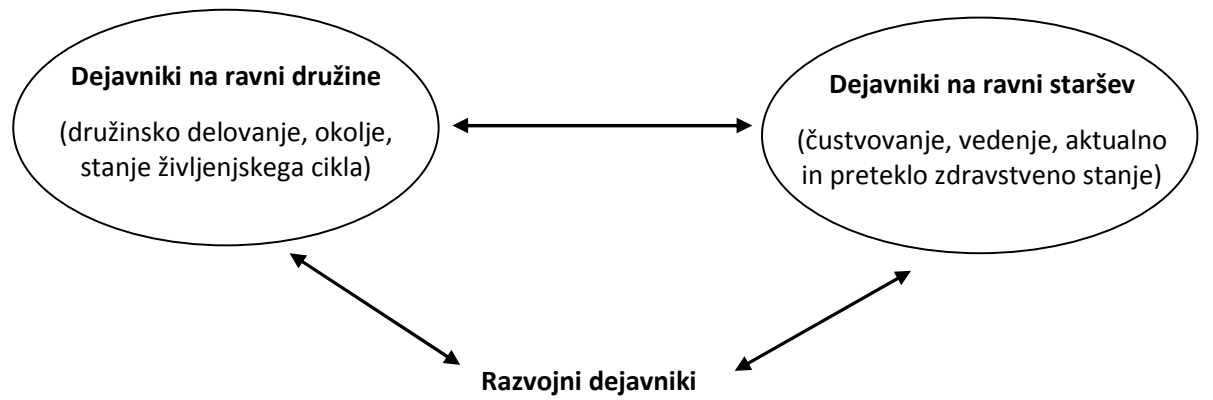

(telesne, psihološke, socialne in čustvene spremembe)

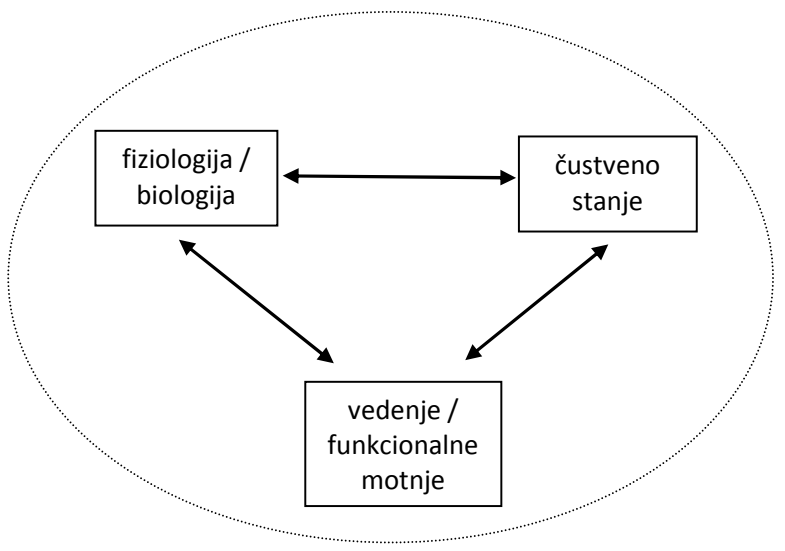

Slika 2. Razvojna perspektiva družinskega in starševskega vpliva na razvoj kronične bolečine pri otrocih in mladostnikih (povzeto po Palermo idr., 2014).

pogoj le neugodni dejavniki na ravni družine in staršev, ampak mora biti otrok kot oseba s svojimi psihičnimi procesi (mišljenje, čustvovanje, vedenje) in biološkimi značilnostmi dovzeten za razvoj tovrstne simpotmatike (slika 2).

Pogosti dejavniki tveganja so prisotni tudi v drugih socialnih okoljih, predvsem $\mathrm{v}$ medvrstniških odnosih, $\mathrm{v}$ katerih so otroci in mladostniki, ki se spoprijemajo s kroničnimi bolečinami, žrtve nasilja (fizičnega in/ali psihičnega) (Schechter, Palermo, Walco in Berde, 2009). Otroci s kroničnimi bolečinami pogosto poročajo o mobingu in zasmehovanju v medvrstniških odnosih (Palermo idr., 2014).

\section{Posledice kronične bolečine pri otrocih in mladostnikih}

Tako kot so dejavniki tveganja za razvoj kronične bolečine biopsihosocialni, takšne so tudi posledice spoprijemanja $\mathrm{s}$ to simptomatiko. Posledice zajamejo posameznika kot individualno osebo (njegovo čustvovanje, mišljenje, vedenje), hkrati pa se prenesejo tudi na njegovo socialno vključevanje. Pri otrocih in mladostnikih, ki se spoprijemajo s kronično bolečino, se pogosto in pričakovano razpoloženje zniža. Prevladuje anksiozno-depresivna simptomatika, ki je po nekaterih podatkih prisotna pri več kot četrtini otrok in mladostnikov s kronično bolečino (Van Tilburg, Spence, Whitehead, Bangdiwala in Goldston, 2011). Pogosto se pojavi strah, ki je vezan na prihodnost (Kaj ta bolečina pomeni zame? Kako bo v prihodnosti?) in na gibanje. Posameznik $\mathrm{z}$ bolečino pričakuje, da bo gibanje bolečine še okrepilo.
Lahko se razvije tako imenovan strah pred gibanjem. Prav tako pogosti so tudi občutki nemoči in katastrofične misli o bolečini. Zaznavamo lahko magnifikacije, kar pomeni, da dajejo ukvarjanju $\mathrm{z}$ bolečino osrednji prostor $\mathrm{v}$ svojem življenju, ter ruminacije - nenehne in ponavljajoče se misli o bolečini (Carr, 2016; Friedrichsdorf idr., 2016; McKillop in Banez, 2016).

Doživljanje kronične bolečine zavzame več vidikov, vezanih na šolo, in sicer vključevanje in sodelovanje v šoli, socialno delovanje in učno uspešnost ter učinkovitost (Chin Chi Chan, Piira in Betts, 2005). V študiji z velikim vzorcem otrok ( $N=749$ šolskih otrok) so ugotavili, da je $19 \%$ otrok z bolečinami v križu zaradi simptomatike izostajalo od pouka (Roth-Isigkeit, Thyen, Stöven, Schwarzenbergerin Schmucker, 2005). V tej študiji so avtorji izpostavili, da se nezmožnost delovanja ne sme meriti zgolj skozi število dni odsotnosti od šole, ampak bolj celostno v smislu udeleženosti ter zmožnosti sodelovanja pri šolskem delu ter aktivnostih. Pogosta težava, vezana na kronično bolečino, se v šolskem okolju kaže v okrnjenem sodelovanju pri športni vzgoji. Ta predmet ne doprinaša le $h$ kondiciji otroka in njegovi koordinaciji, ampak krepi tudi občutek vključevanja in sodelovanja v skupini. Chalkiadis (2001) je v svoji raziskavi ugotovil, da kar $71 \%$ otrok s kronično bolečino ni zmoglo sodelovati v športnih aktivnostih. Čas spoprijemanja $\mathrm{z}$ bolečino je povezan $\mathrm{Z}$ udeležbo v športnih aktivnostih - otroci, ki bolečino doživljajo dlje časa, se redkeje vključujejo v športne aktivnosti (Sjolie, 2004). Proces reintegracije po daljši odsotnosti zaradi kronične bolečine je lahko za otroka zelo stresen. Otroke skrbi, kako bodo nadoknadili zamujeno učno snov. Lahko imajo občutek, da so izgubili stik s sošolci in drugimi vrstniki. Pogosto se 
soočajo s spremenjenim vedenjem (bolečinsko vedenje) in posledičnim posmehovanjem ter nerazumevanjem s strani sošolcev. Pojavljajo se skrbi, vezane na situacije in izvedbo aktivnosti, kot so na primer hoja med učilnicami z bolečino, nošenje težke torbe, sedenje pri urah (Walker, 2004). Otroci s kronično bolečino pogosteje poročajo o jezljivosti staršev ter nekakovostnih družinskih odnosih (Liakopoulou-Kairis idr., 2002). Jeza, osiromašena komunikacija in manj učinkoviti načini spoprijemanja lahko otežujejo sodelovanje med družino otroka s kronično bolečino in strokovnimi delavci šole. Nepoznavanje biopsihosocialnega ozadja kronične bolečine lahko strokovne delavce zavede in si vedenje otroka ter družine razlagajo kot izogibanje šolskim obveznostim, zaščitniško vedenje staršev, pomanjkanje motivacije za učenje ... Neprimerno se lahko odzivajo tudi sošolci in otroka z bolečino doživljajo kot drugačnega, ga izključijo iz svoje družbe, ali nad njim izvajajo psihično in/ali telesno nasilje (Boey in Goh, 2001). Otroci s kronično bolečino poročajo o višji stopnji anksioznosti v socialnih situacijah kot otroci brez bolečine (Meijer, Sinnema, Bijstra, Mellenbergh in Wolters, 2000). V velikem vzorcu otrok s kronično bolečino $(N=2017)$ jih je $71 \%$ poročalo o rednih težavah s spanjem (Chalkaidis, 2001). Motnje spanja pri otrocih pa se povezujejo z motnjami selektivne pozornosti, koncentracije, spoznavnih sposobnosti in spomina (Dahl, 1996), prav tako pa doprinašajo $\mathrm{k}$ vedenjskim težavam ter manj učinkovitemu socialnemu delovanju (Mindell, Owens, Carskadon, 1999).

\section{Psihološka obravnava bolečine}

Psihološko obravnavo je potrebno načrtovati glede na otrokove kognitivne sposobnosti, osebnostne značilnosti, njegovo čustveno stanje, družinske značilnosti ter značilnosti socialnega okolja in stopnjo razumevanja koncepta bolečine. Razvoj otrokovega koncepta bolečine oblikujeta njegova trenutna stopnja kognitivnega razvoja (Piagetova teorija kognitivnega razvoja) in njegove izkušnje z bolečino. Do 18. meseca starosti lahko otroci o doživljanju bolečine poročajo preko joka in/ali s preprostimi in osnovnimi besedami (npr. Au!), ne zmorejo pa sporočati o različnih oblikah in stopnjah bolečine. Otroci okrog 18. meseca starosti lahko svojo bolečino lokalizirajo v lastnem telesu, prav tako lahko prepoznajo bolečino drugih. Razumejo, da lahko zdravila, objemi in poljubi bližnjih njihovo bolečino blažijo. Tudi sami skušajo pomembnim drugim $\mathrm{v}$ bolečini pomagati $\mathrm{s}$ tem, da jih objamejo. Pri starosti dveh let se pojavi kompleksnejše opisovanje bolečine, otroci pa zmorejo vzrok bolečine bolj jasno povezati z zunanjimi izvori. Pri starosti 3 ali 4 let zmorejo otroci razlikovati med različno jakostjo in obliko bolečine. O tem lahko tudi poročajo. Večinoma prepoznavajo le en vzrok bolečine. Med 5. in 7. letom so zmožni bolečino doživljati kompleksnejše - prepoznavajo več vzrokov, prav tako pa lahko različne jakosti povežejo s čustvenim doživljanjem, ki se kaže v obraznem izrazu. Med 7. in 10. letom lahko razložijo, zakaj bolečina boli; v puberteti pa razumejo in lahko razložijo tudi pozitivne funkcije bolečine in njeno vlogo pri zaščiti človeka (Carr, 2016).

Opisane značilnosti je potrebno upoštevati v vseh fazah psihološke obravnave, ki zajema kliničnopsihološko oceno z oceno bolečine ter terapevtsko obravnavo, ki je vezana tako na otroka/mladostnika kot tudi na celotno družino (Carr, 2016).

\section{Kliničnopsihološko ocenjevanje in ocena bolečine}

Biopsihosocialni model izpostavlja pomen posameznikovih značilnosti ter njegovega načina doživljanja, zato je $\mathrm{v}$ obravnavi bolečine pomembno, da v sklopu kliničnopsihološke ocene pridobimo oceno posameznikovih značilnosti ter oceno njegovega doživljanja bolečine. Sodobna literatura s področja ocene bolečine pri otrocih (npr. American Pain Society, 2012; Carr, 2016) navaja pomen prepoznavanja dejavnikov tveganja za razvoj kronične bolečine, sprožilnih dejavnikov, vzdrževalnih dejavnikov ter varovalnih dejavnikov. Oceno pridobimo s pomočjo usmerjenega psihološkega intervjuja ter uporabo standardiziranih vprašalnikov in kliničnopsiholoških preizkusov, ki so lahko namenjeni otrokom in/ali njihovim skrbnikom.

Kliničnopsihološka ocena posameznikovih značilnosti zajema oceno lastnosti, ki so v literaturi (Carr, 2016; Friedrichsdorf idr., 2016; Scottish Government, 2018) omenjena kot dejavniki tveganja za razvoj kronične bolečine. Sem spada ocena:

- posameznikovih intelektualnih sposobnosti in kognitivnih sposobnosti,

- osebnostnih značilnosti,

- čustvenih in vedenjskih značilnosti,

- značilnosti spoprijemanja s stresom,

- prilagoditvene sposobnosti.

Testno baterijo sestavimo iz standardiziranih psiholoških testov, vprašalnikov in lestvic. Kot ocenjevalce pa vključimo tudi otrokove skrbnike (Carr, 2016).

Pri oceni bolečine pa je pomembno, da pridobimo podatke o:

- značilnostih bolečine (zgodovina pojavljanja bolečine, njena intenziteta $\mathrm{v}$ različnih situacijah, kvaliteta bolečine (npr. pekoča, zbadajoča ...), položaj, raznolikost bolečine, predvidljivost pojavljanja) ter

- otrokovih zmožnostih spoprijemanja z bolečino (vpliv bolečine na kakovost življenja, spanje, prehranjevanje, šolske obveznosti in učinkovitost, fizične aktivnosti, družinske in vrstniške odnose) (American Pain Society, 2012; Carr, 2016; Friedrichsdorf idr., 2016; Scottish Government, 2018).

Ob vsem naštetem moramo upoštevati tudi razvojno stopnjo otroka. Otroci do dveh let starosti lahko poročajo lr o tem, da jih boli. Med 3. in 4. letom zmorejo ločiti med različnimi jakostmi in kvaliteti bolečine, zato jih lahko vprašamo, koliko bolečine čutijo (npr. malo, dosti, zelo dosti) in o tem, kakšna je ta bolečina (npr. pekoča, zbadajoča ...). Med 5. in 7. letom starosti otroci že bolj razlikujejo med različnimi stopnjami bolečine, ki jo zmorejo povezati s čustvenim izrazom. Otroci $\mathrm{v}$ tej starosti zmorejo bolečino oceniti s pomočjo slikovnih ocenjevalnih lestvic (npr. ocenjevalna lestvica z obrazi). Od 
7. leta starosti pa lahko bolečino ocenjujejo tudi s pomočjo vprašalnikov, ki obsegajo področje doživljanja bolečine ter njeno simptomatiko, dovzetnost za razvoj in vzdrževanje bolečine, somatizacijo ter na zdravje vezano kakovost življenja (Carr, 2016). Kakovostna kliničnopsihološka ocena nam nudi vpogled $\mathrm{v}$ otrokovo psihološko procesiranje ter razumevanje. Je podlaga za načrtovanje terapevtskega dela.

\section{Kliničnopsihološki terapevtski pristopi in tehnike}

Zaradi večrazsežnostnega delovanja kronične bolečine je za pozitivne terapevtske učinke ključna čim zgodnejša terapevtska obravnava (American Pain Society, 2012). Primarni cilj obravnave predstavlja izboljšanje učinkovitosti na vseh področjih posameznikovega delovanja ter izboljšanje kakovosti življenja (American Pain Society, 2012). V sodobni psihološki obravnavi kronične bolečine pri otrocih in mladostnikih prevladujejo pristopi kognitivno-vedenjske ter sistemske terapije, ki so z dokazi najbolj podprti (Carr, 2016; Coakley in Wihak, 2017; Eccleston in Crombez, 2017; Scottish Government, 2018; Stahlschmidt idr., 2016). Pri delu z otroki je ves čas ključno sodelovanje s starši oz. skrbniki, ki pomagajo pri oceni otrokovega stanja ter pri uvajanju terapevtskih pristopov v vsakdanje življenje (Friedrichsdorf idr., 2016).

\section{Terapevtski odnos}

Da bi naše terapevtsko delo in sodelovanje $\mathrm{z}$ otrokom ali mladostnikom bilo čim bolj kvalitetno, je pomembno zgraditi dober terapevtski odnos in delovno alianso (Carr, 2016; Stewart in Joines, 2002). Tudi otroci in mladostniki potrebujejo čas, da ga začutijo in vzpostavijo. Otrokom in mladostnikom se ob vzpostavljanju odnosa približamo preko uglašenosti na njihove potrebe, želje, zmožnosti razumevanja in doživljanja (npr. dogovorimo se in se v sklepnem delu srečanja skupaj poigramo igro, ki jo ima otrok ali mladostnik rad; dovolimo mu, da nam predstavi igro, ki jo rad igra, interesno dejavnost, s katero se ukvarja; uporabljamo besede, ki jih zmore razumeti itd.) (Malchiodi, 1999). Prav tako je pomembno, da otrok in njegova družina dobijo občutek, da je terapevtski odnos varen in pomemben za proces spoprijemanja $\mathrm{z}$ bolečino (Carr, 2016). Ker bolečina ni vidna navzven, lahko dobijo otroci s kronično bolečino izkušnjo, da strokovnjaki njihovih sporočil ne razumejo. V takih situacijah se na njih uglasimo s tem, da jim damo možnost poročanja o simptomih na njim ustrezen način (izdelajo svoje lastne bolečinske lestvice, lokalizirajo bolečino znotraj telesa ali izdelajo simbole, ki ponazarjajo bolečino, omogočajo vidno predstavo njihove izkušnje, kar pomaga pri sproščanju notranje napetosti) (Angheluta in Lee, 2011; Malchiodi, 1999) Predvsem mlajši otroci o svojih težkih občutkih, ki jih sproža bolečina (npr. strah, nemoč, jeza), poročajo preko igre. Malchiodi (1999) tovrstne pristope pojmuje kot ustvarjalne, ki pa ne smejo predstavljati zamenjave za z dokazi podprte intervence, o katerih pišemo v nadaljevanju, ampak pomagajo predvsem pri krepitvi terapevtskega odnosa.

\section{Psihoedukacija}

Ko imamo anamnezo otroka ali mladostnika, oceno njegovih kognitivnih sposobnosti in čustvovanja ter vpogled v značilnosti njegovega doživljanja bolečine, je pomembno, da vključimo razlago o bolečini oz. razlago o tem, kako deluje. To pomeni, da posameznika izobrazimo, mu nudimo informacije o bolečini, delovanju njegovega telesa in njega kot celote. Edukacija predstavlja pripravo na terapevtsko delo (American Pain Society, 2012). Otroku ali mladostniku razložimo, da je evolucijska funkcija bolečine $\mathrm{v}$ tem, da deluje kot alarm, ki opozori na nevarnost. Kronična bolečina to funkcijo izgubi in je pomembno, da posameznik, ki se z njo spoprijema, dobi sporočilo, da bolečina, ki jo doživlja, ni nevarna (Carr, 2016). To naredimo preko psihoedukacije, ki je temeljna komponenta večinskih pristopov pri obravnavi kronične bolečine pri otrocih in mladostnikih (Carr, 2016; Friedrichsdorf, 2016). Edukacija vključuje razlago, kako in zakaj lahko psihološke strategije učinkovito zmanjšajo bolečino ter na bolečino vezan stres in izboljšajo vsakdanje delovanje. Cilj tovrstne edukacije je predstaviti pacientom povezavo med fiziološkimi in psihološkimi procesi ter njihovo vključenost $v$ intenziteto bolečine. Pomembno je, da otroci razumejo, da neprijetne misli in čustva vzdražijo osrednji živčni sistem in sprožijo številne telesne odzive (npr. pospešijo dihanje, srčni utrip, vplivajo na potenje ...) ter krepijo bolečinski odziv. Razumevanje dogajanja v njihovem telesu je izhodišče za uvajanje pristopov, ki vodijo v spreminjanje stanja. Temeljni cilj je, da bi starši in otroci skozi edukacijo pridobili vpogled $\mathrm{v}$ to, da kronična bolečina ne pomeni nevarnosti (Carr, 2016). Pri edukaciji otrok in mladostnikov je potrebno imeti v mislih njihovo starost ter zmožnost razumevanja razlage. Potrebno se jim je približati in jim razlago podati na način, ki jim je razumljiv in zanimiv. Način in vsebina edukacije morata biti prilagojena otrokovi starosti in njegovim sposobnostim. Poskrbeti moramo, da jo bo res razumel, saj lahko izobraževanje o bolečini otrokom pomaga, da jo začnejo doživljati na drugačen način. Ko gre za predšolske otroke, je psihoedukacija namenjena predvsem njihovim staršem, saj je otroci še ne zmorejo razumeti. Ko so otroci starejši (ali ko obravnavamo mladostnika), je prav tako priporočeno, da je v edukacijo vključena celotna družina (Carr, 2016).

\section{Spremljanje simptomov}

$\mathrm{K}$ prepoznavanju in razumevanju spreminjanja bolečine lahko pomembno doprinese tudi spremljanje bolečinske simptomatike. Spremljanje lahko izvajamo $s$ pomočjo dnevnika (Carr, 2016; Friedrichsdorf idr., 2016). Skupaj z otrokom ali mladostnikom izdelamo tabelo in se dogovorimo, da spremljajo svojo bolečino skozi teden. Njihova naloga je, da sproti beležijo aktivnosti, ki jih izvajajo, situacijo, v kateri so, in stopnjo bolečine, ki je pri tem prisotna. Če gre za starejše otroke ali otroke, ki zmorejo razumeti in prepoznati misli in čustva, si zabeležijo tudi to (mlajši po navadi ob aktivnosti narišejo, kako so se ob tem zaradi bolečine počutili, saj tak prikaz najbolj razumejo). Pri mlajših otrocih 
razložimo pomen naloge tudi staršem in v primerih, ko otroci še ne zmorejo kompleksnega mišljenja, povezovanje situacij z jakostjo bolečine namesto otrok opravijo starši (Carr, 2016).

\section{Tehnike sproščanja in tehnike telo-um}

Bolečina deluje ogrožujoče oz. kot alarm, da je s posameznikom nekaj narobe, zato je pogosta reakcija na spoprijemanje z bolečino strah, ki doživljanje še intenzivira. Osnovni cilj, ki ga želimo doseči, je pridobitev vpogleda $\mathrm{v}$ to, da bolečina ni nevarna, da pa sproža neprijetne in težke odzive, ki delujejo ogrožujoče, a lahko posameznik z zavestnim delovanjem vpliva na njih. Pomembna psihološka intervenca, s katero lahko podpremo otroke in mladostnike ter jim pokažemo, da lahko sami sovplivajo na delovanje svojega telesa, so tehnike sproščanja, vizualizacije in zavedanja (čuječnosti) (Carr, 2016). V tujini so poznane tudi pod imenom "body-mind" oz. telo-um tehnike, saj opozarjajo na celostno delovanje posameznika. Tehnike sproščanja (npr. dihanje, avtogeni trening, mišično sproščanje) so usmerjene v učenje specifičnih sposobnosti, preko katerih bi posameznik zmogel vplivati na delovanje avtonomnega živčnega sistema in s tem doprinesel $\mathrm{k}$ manj intenzivnemu doživljanju bolečine (Palermo idr., 2014). Čuječnost pomeni zavedanje sebe v tem trenutku (zavedanje misli, občutkov, čustev) in brez vrednotenja (Hadhazy, Ezzo, Creamer in Berman, 2000; Palermo idr., 2014). Večina tovrstnih tehnik je prilagojenih oz. posebej oblikovanih za otroke (npr. dihanje z balončkom), zato je pomembno, da izberemo tiste, za katere menimo, da jih otrok ali mladostnik zmore glede na svojo starost, sposobnosti razumevanja in razvojno stopnjo (Friedrichsdorf idr., 2016; Malchiodi, 1999). Friedrichsdorf s sodelavci (2016) poroča, da so se otroci pri starosti 5 let sposobni naučiti nekatere od obravnavanih tehnik in jih vključiti v vsakdanje življenje. Pomembno pa je, da tehnike naučimo tudi njihove starše ter jim predstavimo njihov pomen, saj so tisti, ki otroku pomagajo pri uvajanju tehnike v vsakdanje življenje (Friedrichsdorf idr., 2016). Med vire sproščanja je zelo pomembno vključiti tudi posameznikove interesne dejavnosti ob katerih prepoznava, da ga sproščajo in doprinašajo k dobremu počutju.

\section{Kognitivne strategije spoprijemanja}

Osredotočenost otrok na njihovo bolečino, njihov način doživljanja bolečine ter vedenjski vzorci, ki jih ob tem razvijejo, krepijo njihovo dovzetnost za somatizacijo. Iz tega razloga je priporočljivo, da se otroci naučijo distrakcije, ki blaži razmišljanje o bolečini ter jim pomaga, da se vključijo v aktivnosti, ki jih sproščajo in ne krepijo bolečinskega vedenja. Oblikujejo lahko svojo lastno rutino, ki jo pričnejo izvajati, ko opažajo, da se bolečina krepi (npr. poslušanje glasbe, igranje z najljubšo igračo, igranje računalniške igre ...) (Carr, 2016). Otroke in mladostnike, ki doživljajo bolečino zelo katastrofično, učimo tudi kognitivne restrukturacije, ki jim pomaga, da pričnejo bolečino doživljati kot manj zastrašujočo (Carr, 2016).

\section{Spremljanje simptomatike}

Ob integraciji v vsakdanje življenje otroci in mladostniki spreminjajo skriptni sistem in izstopajo iz področja varnega. Četudi uveljavljeni vzorec delovanja za njih ni bil najbolj učinkovit, je bil varen, ker jim je bil poznan. Učenje in uvajanje novega lahko predstavlja nevarnost, zaradi česar lahko opuščajo, kar so se naučili skozi terapevtske obravnave (Stewart in Joines, 2002). Zaradi tega je pomembno, da nadaljujemo s spremljanjem otroka in da doma to počnejo tudi njihovi starši. Carr (2016) izpostavlja, da je nagrajevanje ena od bolj učinkovitih starševskih aktivnosti.

\section{Zaključek}

Kroničnabolečinaje pogostzdravstveni zaplet, ki lahko doleti otroka ali mladostnika. Posledično lahko zajame njegovo celotno delovanje in vpliva na družinsko življenje. Ukvarjanje $\mathrm{s}$ to problematiko je zaradi tega zelo pomembno. V prispevku smo podrobneje opisali kliničnopsihološko ocenjevanje in najučinkovitejše ter $\mathrm{z}$ dokazi podprte pristope $\mathrm{k}$ obravnavi bolečine. Želimo, da je podani pregled področja $\mathrm{v}$ pomoč strokovnjakom pri njihovem delu z otroki in mladostniki, ki se spoprijemajo s kronično bolečino. Pomembno pa je izpostaviti predvsem to, da je celotno terapevtsko obravnavo potrebno oblikovati tako, da upoštevamo posameznikove individualne značilnosti.

\section{Literatura}

American Pain Society. Assessment and Management of Children with Chronic Pain: A Position Statement from the American Pain Society. Pridobljeno s strani http:// americanpainsociety.org/uploads/get-involved/pediatricchronic-pain-statement.pdf

Angheluta, A. M. in Lee, B. K. (2011). Art therapy for chronic pain: Applications and future directions. Canadian Journal of Counselling and Psychotherapy, 45(2), 112-131.

Balague, F., Skovron, M., Nordin, M., Dutoit, G., Pol, L. R. in Waldburger, M. (1995). Low back pain in school children: A study of familial and psychological factors. Spine, 20, 1265-1270.

Balague, F., Troussier, B. in Salminen, J. J. (1999). Nonspecific low back pain in children and adolescents: Risk factors. European Spine Journal, 8, 429-438.

Boey, C. C. M. in Goh, K. L. (2001). The significance of lifeevents as contributing factors in childhood recurrent abdominal pain in an urban community in Malaysia. Journal of Psychosomatic Research, 51, 559-562.

Brattberg, G. (1994). The incidence of back pain and hadache among Swedish school children. Quality of Life Research, $3,27-31$.

Carr, A. (2016). Somatic problems. V A. Carr (ur.), Child and adolescent clinical psychology: A contextual approach (3. izd, str. 509-574). London, Združeno Kraljestvo: Routledge. 
Chalkiadis, G. A. (2001). Management of chronic pain in children. The Medical Journal of Australia, 175(9), 476-479.

Chin Chi Chan, E., Piira, T. in Betts, G. (2005). The school functioning of children with chronic and recurrent pain. Pediatric Pain Letter, 7(2-3), 11-16.

Chitkara, D. K., Rawat, D. J. in Talley, N. J. (2005). The epidemiology of childhood recurrent abdominal pain in Western countries: A systematic review. The American Journal of Gastroenterology, 100, 1868-1875.

Coakley, R. in Wihak, T. (2017). Evidence-based psychological interventions for the management of pediatric chronic pain: New directions in research and clinical practice. Children, 4(2), 9.

Compas, B. E. (1987). Coping with stress during childhood and adolescence. Psychological Bulletin, 101, 393-403.

Compas, B. E., Connor-Smith, J. K., Saltzman, H., Thomsen, A. H. in Wadsworth, M. E. (2001). Coping with stress during childhood and adolescence: Problems, progress, and potential theory and research. Psychological Bulletin, 127, 87-127.

Conte, P. M., Walco, G. A. in Kimura, Y. (2003). Temperament and stress response in children with juvenile primary fibromyalgia syndrome. Arthritis \& Rheumatology, 48, 2923-2930.

Dahl, R. E. (1996). The impact of inadequate sleep on children's daytime cognitive function. Seminars in Pediatric Neurology, 3, 44-50.

Di Lorenzo, C., Colletti, R. B., Lehmann, P., Boyle, J. T., Gerson, W. T., Hyams, J. S., Squires, R. H., Jr., Walker, L. S. in Kanda, P. T. (2005). Chronic abdominal pain in children: A technical report of the American Academy of Pediatrics and the North American Society for Pediatric Gastroenterology, Hepatology and Nutrition. Journal of Pediatric Gastroenterology Nutrition, 40, 249-261.

Donnelly, T. J. in Jaaniste, T. (2016). Attachment and chronic pain in children and adolescents. Children, 3(4), 21.

Eccleston, C.inCrombez, G. (2017). Advancing psychological therapies for chronic pain. F1000Research, 6, 461.

Egger, H. L., Costello, E. J., Erkanli, A. in Angold, A. (1999). Somatic complaints and psychopathology in children and adolescents: Stomach aches, musceloskeletal pains, and headache. Journal of the American Academy of Child and Adolescent Psychiatry, 38, 852-860.

Friedrichsdorf, S. J., Giordano, J., Desai Dakoji, K., Warmuth, A., Daughtry, C. in Schulz, C. A. (2016). Chronic pain in children and adolescents: Diagnosis and treatment of primary pain disorders in head, abdomen, muscles and joints. Children, 3(4), 42.

Gold, J. J., Mahrer, N. E., Yee, J. in Palermo, T. M. (2009). Pain, fatigue, and health-related quality of life in children and adolescents with chronic pain. The Clinical Journal of Pain, 25, 407-412.

Goldenberg, H. in Goldenberg, I. (ur.). (2008). Family therapy: An overview (7. izd.). Belmont, CA, ZDA: Thomson Higher Education.

Hadhazy, V. A., Ezzo, J., Creamer, P. in Berman, B. M. (2000). Mind-body therapies for threatment of fibromyalgia: A systematic review. Journal of Rheumatology, 27, 2911-2918.
Hassett, A. L., Hilliard, P. E., Goesling, J., Clauw, D. J., Harte, S. E. in Brummett, C. M. (2013). Reports of chronic pain in childhood and adolescence among patients at a tertiary care pain clinic. The Journal of Pain, 14, 1390-1397.

Holley, A. L., Wilson, A. C., Noel, M. in Palermo, T. M. (2016). Post-traumatic stress symptoms in children and adolescents with chronic pain: A topical review of the literature and proposed framework for future research. European Journal of Pain, 20, 1371-1383.

Huguet, A., Tougas, M. E., Hayden, J., McGrath, P. J., Chambers, C. T., Stinson, J. N. in Wozney, L. (2016). Systematic review of childhood and adolescent risk and prognostic factors for recurrent headaches. The Journal of Pain, 17, 855-873.

Jones, G. T., Watson, K. D., Silman, A. J., Symmons, D. P. M. in Macfarlane, G. J. (2003). Predictors of low back pain in British schoolchildren: A popolation-based prospective cohort study. Pediatrics, 111(4 Pt 1), 822-828.

King, S., Chambers, C. T., Huguet, A., MacNevin, R. C., McGrath, P. J., Parker, L. in MacDonald, A. J. (2011). The epidemiology of chronic pain in children and adolescents revisited: A systematic review. Pain, 152, 2729-2738.

Lewandowski, A. S., Palermo, T. M., Stinson, J., Handley, S. in Chambers, C. T. (2010). Systematic review of family functioning in families of children and adolescents with chronic pain. The Journal of Pain, 11(11), 1027-1038.

Liakopoulou-Kairis, M., Alifieraki, T., Protagora, D., Korpa, T., Kondyli, K., Dimosthenous, E., ... Kovanis, T. (2002). Recurrent abdominal pain and headachepsychopathology, life events and family functioning. European Child \& Adolescent Psychiatry, 11, 115-122.

Litt, M. D., Shafer, D. M., Ibanez, C. R., Kreutzer, D. L. in Tawfik-Yonkers, Z. (2009). Momentary pain and coping in temporomandibular disorder pain: Exploring mechanisms of cognitive behavioral treatment for chronic pain. Pain, 145, 160-168.

Malchiodi, C. A. (ur). (1999). Medical art therapy with children. London, Združeno Kraljestvo: Kingsley.

McKillop, H. N. in Banez, G. A. (2016). A broad consideration of risk factors in pediatric chronic pain: Where to go from here? Children, 3(4), 38.

Meijer, S. A., Sinnema, G., Bijstra, J. O., Mellenbergh, G. J. in Wolters, W. H. (2000). Social functioning in children with a chronic illness. Journal of Child Psychology and Psychiatry, 41, 309-317.

Mindell, J. A., Owens, J. A. in Carskadon, M. A. (1999). Developmental features in sleep. Child and Adolescent Psychiatric Clinics of North America, 8, 695-725.

Nicholson, R. A., Houle, T. T., Rhudy, J. L. in Norton, P. J. (2007). Psychological risk factors in headache. Headache, 47, 413-426.

Page, M. G., Stinson, J., Campbell, F. Isaac, L in Katz, J. (2013). Identification of pain-related psychological risk factors for the development and maintenance of pediatric chronic postsurgical pain. Journal of Pain Research, 6, 167-180.

Palermo, T. M. (2000). Impact of recurrent and chronic pain on child and family daily functioning: A critical review of the literature. Journal of Developmental \& Behavioral Pediatrics, 21(1), 58-69. 
Palermo, T. M., Valrie, C. R. in Karlson, C. W. (2014). Family and parent influences on pediatric chronic pain: A developmental perspective. American Psychologyst, 69(2), 142-152.

Roth-Isigkeit, A., Thyen, U., Stöven, H., Schwarzenberger, J. in Schmucker, P. (2005). Pain among children and adolescents: Restrictions in daily living and triggering factors. Pediatrics, 115, 152-162.

Schechter, N. L., Palermo, T. M., Walco, G. A. in Berde, C. B. (2009). Persistent pain in children. V S. M. Fishman, J. C. Ballantyne in J. P. Rathmell (ur.), Bonica's management of pain (4. izd., str. 767-782). Philadelphia, PA, ZDA: Lippincott Williams in Wilkins.

The Scottish Government, Scottish Medical and Scientific Advisory Committee (2018). Management of chronic pain in children and young people: A national clinical guideline: An opportunity for consultation. Pridobljeno s strani https://www.researchgate.net/publication/315661349 Management_of_Chronic_Pain_in_Children_and_Young_People_A_National_Clinical_Guideline

Sjolie, A. N. (2004). Associations between activities and low back pain in adolescents. Scandinavian Journal of Medicine \& Science in Sports, 14, 352-359.

Speretto, F., Brachi, S., Vittadello, F. in Zulian, F. (2015). Musculoskeletal pain in schoolchildren across puberty: A 3-year follow-up study. Pediatric Rheumatology, 13, 16.

Stahlschmidt, L., Zernikow, B. in Wager, J. (2016). Specialized rehabilitation programs for children and adolescents with severe disabling chronic pain: Indications, treatment and outcomes. Children, 3(4), E33.

Stewart, I. in Joines, V. (2002). TA today: A new introduction to transactional analysis. Nottingham, Združeno Kraljestvo: Lifespace Publishing.

Tegethoff, M., Belardi, A., Stalujanis, E. in Meinlschmidt, G. (2015). Comorbidity of mental disorders and chronic pain: Chronology of onset in adolescents of national representative cohort. The Journal of Pain, 16, 1054-1064.

Van Tilburg, M. A., Spence, N. J., Whitehead, W. E., Bangdiwala, S. in Goldston, D. B. (2011). Chronic pain in adolescents is associated with suicidal thoughts and behaviors. The Journal of Pain, 12, 1032-1039.

Voerman, J. S., Vogel, I., Waart, F., Westendorp, T., Timman, R., Busschbach, J. J. V., van de Looij-Jansen, P. in Klerk, C. (2015). Bullying, abuse and family conflict as risk factors for chronic pain among Dutch adolescents. European Journal of Pain, 19, 1544-1551.

Walker, L. S. (2004). Helping the child with recurrent abdominal pain return to school. Pediatric Annals, 33, 128-136.

Walker, L. S., Dengler-Crish, C. M., Rippel, S. in Bruehl, S. (2010). Functional abdominal pain in childhood and adolescence increases risk for chronic pain in adulthood. Pain, 150, 568-572.

Wang, S., Fuh, J., Lu, S. in Juang, K. (2006). Chronic daily headache in addolescents: Prevalence, impact, and medication overuse. Neurology, 66, 193-197. 